\title{
Orwellův svět v roce 2009
}

\author{
Miloslav Petrusek
}

V červnu 1949 vyšla v nakladatelství Harcourt, Brace v New Yorku kniha, která se zařadila mezi několik zásadních beletristických děl 20. století. Svým politickým vyzněním měla otřást totalitními režimy, tímto zrůdným plodem „instrumentální racionality“ a ad absurdum dovedené byrokracie. Pomineme literaturu, jejímž dominantním literárním tématem je kritika nacismu - třebas Feuchtwangerovu triologii, román I ve smrti sami, Mannův esej Bratr Hitler, ale i alegorický př́běh Doktora Fausta či nejslavnější román Heinricha Manna Mefisto, př́padně kritika latinskoamerických autoritářských režimů třebas vynikající román Marquézův Podzim patriarchy nebo romány Carpentierovy Výbuch $v$ katedrále a Náprava dle metody. Setrváme především u literárního obrazu a kritiky sovětského systému. Je jistě věcí individuální zkušenosti (osobní i literární) a do značné míry subjektivní volby, která díla vybereme. Zdá se nicméně, že nejméně tři patří k neopominutelné „klasice“. Jsou totiž nejen formálně často jmenována, ale stále čtena, jsou živá a zřejmě tedy obsahují jakýsi aktualizující náboj, který jim nedovolí zůstat $\mathrm{v}$ řadě strnulé nehybnosti nečtených, leč ctěných klasiků. Myslím, že jde o knihu Artura Koestlera Tma o polednách, která již v roce 1939 odhalila - bez znalosti jakýchkoliv svědeckých či archivních podkladů - mechanismus moskevských procesů, které „otřásly světem“, o žánrově science fiction s titulem 1984 George Orwella a konečně o Solženicynův monument Soustroví Gulag.

Loni jsme si připomněli 60. výročí vydání Orwellovy knihy, která - aniž ji musíme jakkoliv přistřihovat ad usum delphini - je nejen literární výpovědí o minulosti, která se v této podobě sice nestala, ale nesla mnohé její znaky, ale v mnohém je i varováním před budoucností, která se stát může. Minulost, která se nestala? Orwellův román, jehož mnohé detaily nám až nepř́ijemně připomínají reálie nedávné doby, totiž zobrazuje to, co by Max Weber asi nazval ideálním typem totalitní společnosti - společnosti, která nežádá pouhou poslušnost a vnější konformitu (kterou jsme dokázali v době normalizace švejkovsky hrát i karikovat), ale absolutní odevzdání. Vyšetřovatel O’Brien říká hlavnímu hrdinovi Winstonovi (ostatně celý př́běh kromě marginální Julie více „hrdinư “ ani nemá): „Jsme jiní pronásledovatelé než v minulosti. Nespokojíme se s negativní poslušností, ani s nejpodlejší podřízeností. Až se nám konečně podrobíš, uděláš to z vlastní, svobodné vůle." Ačkoliv rozborů Orwellova románu bylo napsáno více než několik desítek (viz bibliografie americké Kongresové knihovny), zůstává doslov Milana Šimečky (zesnulého roku 1990) z let 1981-1983 asi tím nejlepším průvodcem knihou z hlediska konfrontace jejího obsahu s aktuálními zážitky disidentů naší „normalizační epochy“ (a snad retrospektivně i těch mučených, utrápených a dokonce popravených z let padesátých). Všechny ty paralely, které Šimečka uvádí, jsou jistě „pravé“. To podstatné, co však zůstalo nenaplněno v Orwellově hrůzném proroctví, je to, že se žádnému totalitnímu režimu nepodařilo proměnit všechny členy této patologické pospolitosti v oddané a věřící, poslušné a nepochybující. Výjimkou by snad mohlo být nacistické Německo, kde oddanost Vůdci opravdu překračovala zdravý rozum „až do hořkého konce“ a kde by srovnání s devótností vůči Stalinovi pokulhávala na obě nohy. Jak uvedl Šimečka, „kacíře 
převedeme na naši stranu ne vnějškově, ale doopravdy, srdcem, duší, a než ho zabijeme, uděláme $\mathrm{z}$ něho jednoho $\mathrm{z}$ nás“.

A právě zde si začněme klást otázku (věru „historicko-sociologickou“), která se občas v souvislosti s Orwellovým románem také klade - nakolik dnes jde již jen o dějinnou retrospektivu a nakolik jde o text, který otevírá otázky i pro současnost aktuální. Orwell patří k autorům, jehož některé věty patří ke konverzačnímu oběživu: „někteří lidé jsou si rovnější“ z Farmy zvírat, newspeak, doublethink, brainwashing, Velký bratr - ani se je nesnažíme překládat, ostatně to většinou vlastně není ani možné. To ovšem dokládá, že po šedesáti letech nežije jenom románový př́iběh (literárně jistě nijak oslnivý či formálně „sofistikovaný“, naštěstí), ale že žijí především otázky jím položené. Klademe si je? Jak? Umíme na ně odpovědět? Snažíme se o to?

Z hlediska našeho oboru je jistě centrální Orwellův důraz na to, čemu říká stranická poučka - kdo ovládá př́tomnost, ovládá minulost; kdo ovládá minulost, ovládá budoucnost. Tento slogan je možno stejně dobře chápat jako hlubokou výpověd’ o možnostech, které poskytuje manipulace dějinami, i jako pouhý verbalismus, který se prostě nedá „empiricky ověřit“. Zkušenost totalitních režimů ale vede k jednoznačnému a ověřitelnému závěru - těm, kdo vládnou, vždycky mimořádně záleželo a záleží na tom, aby dějiny „vypadaly“ k obrazu režimu, aby z nich bylo vymýceno všechno, co je s oficiální ideologií v rozporu, nebo aby tomu, co bylo, byl dán jiný, třebas obrácený smysl, aby „nepohodlní“ byli z dějin eliminováni nebo degradováni a zneuctěni nejen politicky, ale hlavně lidsky. Proč by si jinak Stalin dal tolik práce s Dějinami VKS(b), kdyby šlo o „pouhé dějiny“? Právě, že o dějiny vůbec nešlo, šlo o novou historickou konstrukci, brutálně lživou - faktograficky i personálně, nemluvě o tom, že i mlčení (například o hladomorech, o počtu obětí vysídlování a násilné kolektivizace) je významná výpověd"

Měli bychom být ale velmi opatrní, ohlížejíce se do minulosti, abychom se vědomě (!) nedopustili orwellovských chyb: existují diferencované interpretace dějů, osobností a událostí, což není totožné s vědomou ideologickou lží nebo aspoň sebeklamem bona fide. Můžeme vést spor o historický relativismus, ale nemůžeme vést spor o elementární fakta; o ta šlo v orwellovském světě především. Někteří krajní vulgarizátoři chtějí v naší soudobé společnosti vidět kus orwellovské společnosti, hauzírují newspeakem, Velkým bratrem a doublethinkem, jako bychom opravdu žili kdesi, kde jsme pod trvalým dozorem, kde jsme nuceni ke slepé (a nepředstírané) loajalitě, kde musíme mluvit předepsaným jazykem a kde musíme žít se schizofrenicky rozpolceným vědomím, v němž jedna polovina ví, jak to bylo, a druhá, jak se to má říkat.

V této podobě jde o literární (a zejména novináři oblíbenou) nadsázku, dokonce myslím, že nepřípustnou. Ačkoliv by ani Orwell asi nebyl tak zcela nadšen z naší liberální demokracie, ona přece jenom nemá hrůznou „místnost č. 1“, ale bohužel ani komfortní cely pro prokazatelné miliardové zloděje, kteří se „daňovým poplatníkům“ vysmívají ze svých honosných sídel, a na něž jsou všichni exekutoři krátcí. Žijeme ve společnosti, v níž se netrápíme strachem před mocnými tohoto světa ani nejsme úplně bezmocní proti pokusům o svévoli úředníků a movitých (většinou dočasně) mocipánů. Jakkoliv křehká naše demokracie je, nedovoluje zneužití moci ani v náznaku, který by připomínal orwellovský svět.

Čeho je asi třeba se reálně bát (v tom je poučení nejen z Orwella, ale také $z$ dějin obecně a ze soudobé sociologie zvláště), je fenomén svádění, na nějž kdysi upozornil 
Jean Baudrillard: svádění v onom širokém sociologickém smyslu, které může fungovat jen ve spotř̌ební společnosti (která má nadbytek zboží a dostatek konzumentů), může vést $\mathrm{k}$ tomu, že mozek člověka - průměrného spotřebitele „vymyje“ až na dno, na němž zůstanou zbytky šampónů, mycích pěn a čistících přípravků spolu s pronikavou vůní kosmetiky a odložených, leč stále svěžích oděvních součástek. O podílu reklamy, médií, billboardů atd. nemá smysl zde vést řeč. Všichni tvrdíme, že „nás to neovlivňuje“ a že je to slaboduché, ale konec konců podvědomě se tím vším velice často řídíme. Toto je vskutku „orwellovský“ moment - manipulace, při níž člověk ani neví (nebo si to nepřipouští), že je manipulován, jej lidsky degraduje. Ale opět, buđ’me zdrženliví, nejde ani daleka o onu degradaci na orwellovskou úroveň, o níž mnohé víme nejen z románu, ale i z historických reálií. Orwell měl ostatně pro svůj obraz sovětského totalitarismu významné předchůdce. Zamjatina s jeho fantaskním románem $M y$, jehož některé motivy převzal, Robakidzeho Vražděnou duši, Kravčenkovo předválečné svědectví o sovětských lágrech, ale i metaforický obraz Bulgakovův v Mistru a Markétce. Za připomenutí stojí, že v „sovětské éře“ (1961) vyšel vynikající fantastický román bratrů Strugackých Je těžké býti bohem (tito autoři napsali předlohu pro slavný Tarkovského film Stalker), kteří popsali totalitní systém snad sociologicky plastičtěji než Orwell, ale v detailech a psychologii postav jistě umírněněji.

Newspeak je osobitý fenomén, který by zasloužil více pozornosti, než se mu dostává: nejde jenom o anglicismy, ty si jazykovědci uhájí. Spíše jde o vliv nových komunikačních médií, které (mobil je tu pars pro toto) nejen vytlačují mezilidskou komunikaci, ale redukují jazyk na elementární sdělení, jež mají reálný smysl snad v polních bojových podmínkách, ale člověka moderní společnosti postupně infantilizují. Sděleno lapidárně: novými technologiemi dekultivujeme, zploštujeme a degradujeme jazyk (aniž to pocitujeme), ergo také znevažujeme vlastní myšlenkovou úroveň. Současně s tím, že „komunikujeme“ na veřejnosti, odkrýváme navíc vlastní intimitu, aniž si to uvědomujeme. Vzniká „novoorwellovský“ fenomén odhalené intimity, jev dosud v civilizovaných zemích (asi od 15. století) neznámý. Ale ještě jednu souvislost nepomiňme, totiž to, čemu se vznešeně říká „politická korektnost“. I ona je nezřídka, zejména ve své „násilnické“ podobě, variantou newspeaku, dokonce přesně ex definitione - „newspeak byl vytvořen proto, aby znemožnil jiné způsoby myšlení, a hlavně proto, aby eliminoval slova nežádoucí a všechny jejich neortodoxní významy“.

A nebojme se říci - celé to orwellovské čištění mozků má svou analogii v infantilizaci, jež se projevuje redukcí četby, odklonem od hudby, jíž se kdysi říkalo vážná, a povýšením některých „estetických žánrů“ na piedestal, na nějž kdysi nepatř̌ily. Tady platí to orwellovské - kdo ovládá tuto současnost, ovládne budoucnost. Dnes k tomu nepotřebuje násilí, ale to, o čem věděli Orwellovi současníci z frankfurtské školy, totiž „kulturní průmysl“.

Konečně doublethink, ono zdvojené myšlení, kdy si paralelně něco myslíme a něco jiného říkáme, není prostým projevem hypokrize, pokrytectví a výrazem strachu v totalitním režimu. Pro naši dobu je prríznačná - jak poprvé a přesně postihl Zygmunt Bauman - ambivalence, což se v jisté specifické podobě asociuje s orwellovským doublethinkem. Fenomén ambivalence psychologové znají velice dobře: jde o současný projev protikladných pocitů, emocí a psychických stavů, např́íklad radosti a smutku, smíchu a pláče, lásky a nenávisti, k čemuž lze dodat (což sociologicky učinil Bauman), že am- 
bivalenci není nutno redukovat na emocionální stavy - i kognitivní, poznávací procesy totiž mohou být ambivalentní. „Tradiční svět“ byl nesrovnatelně jednoznačnější, než je náš - kam zrak tvůj padne, tam dnes narazí na ambivalenci, všechno má své „pro“ a „proti“, čemuž ale také odpovídá strukturace společnosti na zájmové a lobbistické skupiny, na uzavřené sociální sítě, na sídliště, jež připomínají opevněné pevnosti. Ale také individuálně jsme rozpolceni. Permanentně stojíme před volbou mezi nejednoznačně určenými jevy, fakty a procesy, sociálně jsme diferencováni (a nejen výší př́ijmů) - počínaje ekologickými otázkami, jadernou energií či radarem v Brdech a konče značkovým oblečením, vztahem k automobilismu a výstavbě dálnic. Ve spotřební společnosti definované ambivalencí („doublethinkem“) se žije krásně, protože je to společnost voňavá, bohatá, mohovitá, je otevřená volbě a připouští korektní svobodu slova. Ale není to společnost, v níž by nebyly skryty zárodky toho, co se může rozvinout v orwellovský přízrak Velkého bratra - co my o něm při současném stavu techniky a při stavu psychologie permanentního ohrožení vlastně víme?

Není v těchto otázkách větší míra aktuálnosti než v otázce (historicky absolutně zásadní): Proč se to všechno stalo? Jak to bylo možné? Naléhavost té otázky má své tiché echo ve skromné odpovědi: lidé to dopustili svou lhostejností, svou netečností, svou indiferencí a pevnou vírou, že to „někdo“ vyřeší za ně. Vždycky to „někdo“ vyřešil a častokrát se lidé potom, když už bylo pozdě, nestačili divit. A volání „takto jsme si to přece nepředstavovali“, bylo voláním, za něž se šlo do orwellovské „místnosti č. 1“.

Pozn.: Zpracováno v rámci Výzkumného změru Ministerstva škoství, mládeže a tělovýchovy České republiky MSM 002160841. 